Annals of Warsaw University of Life Sciences - SGGW

Horticulture and Landscape Architecture No 41, 2020: 37-49

(Ann. Warsaw Univ. of Life Sci. - SGGW, Horticult. Landsc. Architect. 41, 2020)

DOI 10.22630/AHLA.2020.41.4

\title{
Assessment of spatial cohesion in suburban areas based on physical characteristics of buildings
}

JOANNA KOŁATA, PIOTR ZIERKE

Faculty of Architecture, Poznan University of Technology

\begin{abstract}
Assessment of spatial cohesion in suburban areas based on physical characteristics of buildings. The rapid expansion of residential buildings in suburban areas currently makes these places particularly exposed to spatial degradation, the disappearance of traditional rural landscapes and other various problems. The lack of architectural and urban cohesion of new and existing buildings is one of the reasons for increasing spatial disorder. The subject of the presented research is the physical features of the building forms, which influence spatial order through their role in shaping the spatial context. The authors aimed at creating a method of spatial monitoring based on the characteristics of the physical features of buildings located in a given area. The results of the study are intended to provide in-depth and digestible information on the buildings in individual areas. They should also enable the participants of the construction process to become better acquainted with the local forms of buildings and raise the architectural awareness of inhabitants.
\end{abstract}

Key words: spatial monitoring, spatial cohesion, spatial order

\section{INTRODUCTION}

The rapid expansion of residential buildings which can now be observed in suburban areas, makes these places particularly exposed to spatial degradation, the disappearance of traditional rural landscapes and other various problems. Spatial disorder is not, of course, a new phenomenon; it has been present in Poland for decades. The approach to this problem and the related spatial chaos has changed over the centuries and has been usually based on specific urban designs and cities' construction rules. These rules, among many relics of the past, are a special issue because they have influenced not only the spatial order, but also the principles of the society's existence. Although the origins of urban planning date back to ancient times, and its rules have changed over time, one of them has remained unchanged - the authorities are responsible for designing, organising and managing the space they govern (Kowalewski et al. 2018).

The behaviours formed in the 20th century, as well as those resulting from the political transformation in Poland at the turn of the 20th and 21st century, affects the contemporary spaces of Polish cities and villages. The economic development in recent years has contributed to the dynamic growth of the building sector, which, especially in suburban areas, is the source of many unfavourable processes, characterised by such concepts as chaos and spatial disorder. Increased investment activity, however, does not result in actions taken by the authorities to standardise the planning process. Existing legal acts and the competences of professionals do not ensure spatial order. Residential districts sprawling within 
cities and their surroundings are created in accordance with the applicable law, but their location, shape and relationship with the neighbouring areas are questionable.

As the authors of the Polish Academy of Sciences (Polska Akademia Nauk) report "Studies on Spatial Chaos" emphasise, the effects of political and social negligence are dramatic for the condition of space (Kowalewski and Nowak 2018). They have noticed that the constant devastation of laws and institutions responsible for their preparation and implementation results in a growing collapse.

Spatial chaos is a subject of scientific research primarily because of its origins and its current and future consequences. Apart from further changes in the law, which are of course also necessary, the scientific studies published in recent years have also recommended efforts to develop a system for monitoring processes of spatial planning and development. The creation of such a system is postulated, among others, for instance, in the third volume of the aforementioned Polish Academy of Sciences report (Śleszyński et al. 2018). However, the authors of this document predict that the creation of such a system will be complicated as it requires the unification of evaluation processes (e.g. due to the need to compare the condition of space both within the commune, poviat and a whole country). At the same time, the system should "present the issues in a way that is as digestible as possible for recipients and be generally and easily accessible" (Śleszyński et al. 2018).

Since the overall space monitoring is a complex process and concerns many aspects of spatial planning, the authors have focused on the introduction of a partial monitoring, covering in the first stage the physical features of the building forms. The development of this system and the development of a comprehensive spatial monitoring system will require cooperation with specialists from other areas of design and spatial planning in the coming years. Although the introduction of partial monitoring will not completely solve spatial problems, it will make it possible to compile and to provide people involved in different stages of the construction process, such as officials, planners and architects, with precise information on the physical characteristics of buildings, which are an important spatial element. Such persons should have the widest possible knowledge of local architecture and building forms. The analysis presented in the manuscript is the first stage of works on the monitoring system, which is to be refined and supplemented over the years. The authors hope that the data obtained in the following years will broaden the state of knowledge about developed areas also by obtaining detailed comparative material, which should show the scale and type of spatial changes in the analysed areas.

In order to better illustrate the results of the analysis of the physical characteristics of buildings and to present data on the forms of buildings in a more accessible way (as suggested by the aforementioned Polish Academy of Sciences report), the authors decided to present its results as areas with different degrees of spatial cohesion.

The lack of cohesion of the architectural and urban structure is one of the elements that characterise spatial disorder. 
According to many scientific studies, spatial cohesion is a key element of spatial order (Wdowicka and Mierzejewska 2012), and some researchers even use these terms interchangeably (Kolipiński 2011, Kozłowski et al. 2017). The important role of cohesion in shaping a city is also mentioned by Kantarek (2008, 2010), which she defines as "such a feature that combines its individual parts together". This view is also found in foreign studies. Salingaros (2017) believes that "space is experienced positively only when it is coherent". Caliskan and Mashhoodi (2017) believe that the notion of coherence is the most basic condition of spatial quality within the urban fabric.

This approach is also consistent with the work of older architecture and urban theorists. Alexander (2002) believes that design should combine dependencies in such a way as to create a special balance and consistency in complete design structures, on all scales. In "A Pattern Language" Alexander et al. (1977) write that "when you build a thing you cannot merely build that thing in isolation, but must also repair the world around it, and within it, so that the larger world at that one place becomes more coherent, and more whole". Maki (1964), while explaining the nature of collective form, states that "it is, however, not a collection of unrelated, separate buildings, but of buildings that have reasons to be together". It is also worth mentioning here the very definition of the form of the city by Lynch (1990), i.e. the "spatial arrangement of physical structures and spaces of localised activities and flows on the scale of a community or urban region".
Many of the above definitions of cohesion are obviously very broad and refer to a much broader concept than the form of the buildings themselves, but the characteristics of buildings are always a constituent element, a factor influencing the concept of cohesion.

\section{PURPOSE AND TEST METHODS}

The aim of the study is to create a method of space monitoring based on the physical characteristics of buildings, which, as a result of a synthesis of the obtained results, will make it possible to enable the formulation of guidelines for further development in given areas. The analysis of the individual physical characteristics of buildings was developed with the use of a proprietary method of presenting the results by identifying areas that are coherent, partially coherent, and incoherent, located in the analysed area. This is because, in principle, the results of the research are to be as accessible as possible to the recipients. A presentation which shows the dominant physical features in a given area may be more readable and may characterise areas with dominant features. This is intended to help the participants in the construction process, especially planners, officials responsible for drawing up and giving opinions on planning guidelines, architects, who unfortunately are not always familiar enough with the surroundings of the buildings they design, and, finally, investors, who can more consciously seek building forms that are better suited to the local spatial context. This approach is in line with the 2017 draft of the 
Urban Planning and Construction Code. Article 116, par. 2 of the Code stipulates that "it shall be ensured that an investment project is harmoniously embedded in the immediate surroundings by adapting $[. .$.$] the characteristic external$ parameters of the investment project to the dominant type of the developments in the analysed area" (Projekt z dnia 23 listopada 2017 r. ustawy Kodeks urbanistyczno-budowlany). However, it should be mentioned here that although the principles of the Code were right, and it contained many provisions critically needed for the spatial order, the act itself was not finally passed and work on it was terminated.

Since cohesion analysis has its origins in a branch of mathematics called topology, research works from this very field are the most common. The term is also used to describe social and economic phenomena. Much less frequent are works aimed at measuring spatial cohesion which usually focus on trying to determine the level of cohesion of the urban fabric. In recent years, attempts to define a method for measuring urban cohesion have been made by Ewing and Clemente (2013). In their study they focused on the definition of eight measurable urban indicators, which were then evaluated by means of visual assessment analyses, which were largely based on spatial perception.

The aim of the Caliskan and Mashhoodi study (2017) was to measure urban cohesion more objectively. To this end, they used the Gini-Simpson index, which is a measure of the coherence, equality and proximity of elements in the spatial arrangement.
The method of assessing coherence presented in this paper is an attempt to identify areas where certain physical characteristics of buildings dominate. Such areas have been identified as coherent. Where no predominant physical characteristic features of buildings can be defined in the area, the area was identified as incoherent. The third type of areas identified in the course of this study are partially coherent areas, i.e. areas where there are characteristic physical features of buildings but they are not dominant.

The pilot study was carried out in municipalities of the Poznan area. As the analysis of the whole area is planned to stretch over several years and data collection and compilation is still ongoing, this manuscript presents the results of pilot studies based on the example of the Luboń municipality.

While working on the research method, source literature was studied, mainly in the area of spatial chaos and order, as well as in the area of research on the visual evaluation of space. The tool required experimentation and pilot studies to check the correctness and repeatability of the results obtained. A field query was carried out in the area of Poznan, and cartographic and satellite image analyses were performed. In the course of the works, a questionnaire survey was also used, which made it possible to define the most important physical features of buildings influencing the visual coherence of the space they occupied.

The analysis assessed small areas not exceeding a few urban blocks, which are distinguished by the visual features of the existing buildings. The most impor- 
tant element of this stage of the analysis was to define the criteria for assessing the spatial cohesion. Niezabitowski (2006) writes that "both the building and its surroundings are characterised by a number of physical features that can be perceived visually, such as shape, size, colour, texture, proportions, surface transparency, articulation, decoration and others". The physical characteristics of the forms of the analysed buildings presented in the paper were determined on the basis of the criteria set out in the act referred to above: the Urban Planning and Construction Code, and above all its "urban planning regulations for developed areas". It has been determined that the analysed physical characteristics of buildings will be their height, their location in relation to the road, the type, geometry, colour and material of the roof, maintenance/departure from the existing alignment of the buildings, colour and material of external walls, proportions of the building, ratio of the height of walls to the height of the roof, proportions of window openings, as well as the length and width of the buildings, colour of window and door woodwork, colour of the plinth, and the architectural details in the buildings. However, not all of these features have the same impact on the perception of space, which is usually assessed from the perspective of a person or a passenger using means of transport. The visual impact assessment method distinguishes three visual zones of the environment: near, intermediate and distant, in which the perception of space changes (Niezabitowski 2006). Due to the nature of the survey and its focus on the physical characteristics of buildings, the most important criteria will be those visible in the near zone defined by the maximum distance expressed in tens of metres. Already from such distances and perspectives some features are easier to see than others and actually have more influence on shaping the spatial order and cohesion. The assessment of the importance of the elements of the building form varies depending on the study and the authors. The previously mentioned draft of the Urban Planning and Construction Code indicates the primary role of such building features as the colour of the building, building alignment and roof shape and geometry. Podawca (2016) points to the "height of the buildings and the form of the roof as factors shaping spatial order in Poland". In view of the differences in scientific studies, it was decided to conduct a survey among architects and students of the Faculty of Architecture at the Poznań University of Technology who deal with the issues of physical characteristics of buildings and their impact on spatial order and cohesion as part of classes held at the Research and Design Studio. The aim was to indicate which of the sixteen physical characteristics of the building have the most significant impact on the spatial cohesion. And although only 20 respondents took part in the survey, it helped clarify and supplement the characteristics indicated in the abovementioned studies. The results are presented by percentages depending on the number of votes obtained. Eventually, seven features received a significance rating above $50 \%$ :

- $100 \%$ - height of the building (can be expressed also with the number of its storeys),

- $95 \%$ - location of the building in relation to the road, 
- $95 \%$ - type and geometry of the roof,

- $90 \%$ - maintenance of or deviation from the existing building alignment,

- $85 \%$ - colour of external walls,

- $70 \%$ - proportions of the building (ratio of height to length and width),

- $65 \%$ - colour of the roof,

- $50 \%$ - external wall finishing material,

- $45 \%$ - ratio of wall height to roof height,

- $45 \%$ - proportions of window openings,

- $35 \%$ - width of the building,

- $35 \%$ - length of the building,

- $20 \%$ - roof finishing material,

- $20 \%$ - characteristic details of the building,

- $10 \%$ - colour of window and door frames,

- $5 \%-$ colour of plinths.

The above results indicate that the assessment of the features that have the greatest influence on perception is largely consistent with the abovementioned publications in terms of the colours of the buildings and their roofs, the building alignment, shape and geometry of roofs and building height.

During the survey, accurate measurement of the height of buildings, usually due to a lack of access to them, proved to be a major problem. Due to the desire to keep the widest possible spectrum of the analysed buildings, it was decided to exclude building proportions from the study. Finally, the six criteria were used in the study: height of the building, location of the building in relation to the road, type and geometry of the roof, maintenance of the existing building alignment, colour of external walls, and colour of the roof.

During the pilot study it was noted that a full coherence of all the indicated physical characteristics of buildings is not necessary and an area can be perceived as coherent even though only some of them are compatible. It was noted that three out of six characteristics are sufficient for an area to be visually perceived as coherent.

The benchmark for assessing coherence was the nature of the buildings dominating the surroundings.

Finally, the following definitions of areas that are coherent, partly coherent, and spatially incoherent, were proposed:

- coherent areas - areas which consist of buildings, the majority of which have the same values of at least three out of the following architectural features: height of the building, its location in relation to the road, maintenance of the existing building alignment, type and geometry of the roof, as well as the colour of external walls and the colour of the roof,

- partly coherent areas - areas which consist of buildings which have the same values for at least three of the following architectural features: height of the building, its location in relation to the road, maintenance of the existing building alignment, type and geometry of the roof, as well as the colour of external walls and the colour of the roof, but these buildings do not predominate in this area,

- incoherent areas - areas which consist of buildings which do not share the same values of at least three out of the following architectural features: 
height of the building, its location in relation to the road, maintenance of the existing building alignment, type and geometry of the roof, as well as the colour of the external walls and the colour of the roof.

The correctness of the dominance of physical characteristics in the individual analysed areas, and thus the correctness of the qualification of the areas as coherent, partly coherent and incoherent, has been verified with the dominance index, which is usually used in the biological sense to calculate species prevailing in the biocenosis of the given area. The calculations were based on the formula:

$D=(n / N) \cdot 100 \%$

where:

$D$ - predominance of the analysed physical characteristic, $n$-number of buildings characterised by the presence of the physical feature,

$N$ - total number of buildings in the analysed area.

In order to make the results of the survey more accessible to the public, it was decided to supplement the plans with the location of coherent, partly coherent and inconsistent spaces with a signature system which determines the values of the dominant physical characteristics of buildings in the given area. Each signature consists of seven elements, the first of which is a three-digit land order number, with the next indicating the dominant function of the buildings followed by the value of the six physical characteristics prevailing in the area. The proposed signature designations are shown in Table 1.

\section{COHESION STUDY BASED ON THE EXAMPLE OF THE CITY OF LUBOŃ}

On the basis of the criteria presented in the previous chapter, a study on the cohesion of areas in terms of the dominant physical characteristics of their buildings was carried out in the Lubon commune. Its results presenting the location of areas that are coherent, partially coherent and incoherent are presented in Figure 1.

The analysis made it possible to determine the level of cohesion of the areas in terms of physical characteristics of the buildings situated in them. It turned out that incoherent areas, which occupy just under $63 \%$ of the developed areas, i.e. 470 ha, prevail in Luboń. Coherent areas occupy almost $27 \%$ (203 ha) and partly coherent over $10 \%$ (78 ha). A detailed analysis of the six elements influencing the perceived cohesion, a fragment of which is presented in Table 2, made it possible to define the most important architectural features and the places where the given features prevail, e.g. two-storey buildings, higher buildings. The study showed that there are flat-roofed buildings in most areas, and indicated where buildings with other types of roof (e.g. slanted) predominate. Information was also gathered on the type and colour of the roofing and the dominant colour of the external walls. Thus, during the microscale analysis, comprehensive information was obtained concerning the characteristic features of the Lubon architecture and the places where these features are the most frequent. The areas designated in the study were assigned signatures determining the values of the 
TABLE 1 . The system of signatures proposed for the spatial cohesion study

\begin{tabular}{|c|c|c|}
\hline No & Name & Signature \\
\hline 1 & Serial number & 001-999 \\
\hline 2 & $\begin{array}{l}\text { Dominant function(s) of buildings in } \\
\text { a given area }\end{array}$ & $\begin{array}{l}\text { MN - single-family residential buildings } \\
\text { MW - multi-family residential buildings } \\
\text { U - service areas (shops, craftsmen, etc.) } \\
\text { UP - public service areas (education, sacral facilities, } \\
\text { sports and recreation areas, etc.) } \\
\text { AG - areas of economic activity }\end{array}$ \\
\hline 3 & $\begin{array}{l}\text { Number of overground storeys of } \\
\text { buildings dominating the plot }\end{array}$ & $1-$ one storey $\ldots>10$ \\
\hline 4 & $\begin{array}{l}\text { Dominant roof type } \\
+ \\
\text { approximate pitch }\end{array}$ & $\begin{array}{l}\text { A - pyramid hip roof } \\
\text { C - hip roof } \\
\text { D - gable roof (also asymmetrical) } \\
\text { H - onion roof } \\
\text { K - dome roof } \\
\text { M - mansard roof } \\
\text { N - half-hipped roof } \\
\text { P - butterfly roof } \\
\text { R - curved roof, Delorme roof } \\
\text { S - saw-tooth roof } \\
\text { T - Dutch gable roof } \\
\text { U - shed roof } \\
\text { W - spire roof } \\
\text { X - flat roof } \\
\text { Z - other roof } \\
\end{array}$ \\
\hline 5 & Dominant roof colour & $\begin{array}{l}\mathrm{c}-\text { red, orange } \\
\mathrm{g} \text { - black, grey } \\
\mathrm{r} \text { - brown } \\
\mathrm{n}-\text { blue } \\
\mathrm{i}-\text { other } \\
\end{array}$ \\
\hline 6 & $\begin{array}{l}\text { Building location in relation } \\
\text { to the road }\end{array}$ & $\begin{array}{l}\mathrm{K} \text { - ridged } \\
\mathrm{S} \text { - peaked }\end{array}$ \\
\hline 7 & External walls colour & $\begin{array}{l}\mathrm{b}-\text { white } \\
\mathrm{g}-\text { black, grey } \\
\mathrm{k}-\text { beige } \\
\mathrm{r}-\text { brown } \\
\dot{\mathrm{z}}-\text { bright yellow } \\
\mathrm{o}-\text { orange } \\
\mathrm{o}-\text { pink } \\
\mathrm{z}-\text { green } \\
\mathrm{c}-\text { red }\end{array}$ \\
\hline
\end{tabular}

dominant physical features in the given area. A fragment of the map supplemented with signatures is shown in Figure 2. For example, in the area marked
059.MW.4-5.7.X3g.bgrk, multi-family residential buildings prevail, with four, five and seven storeys, with a flat roof with a pitch close to $3^{\circ}$ and a grey 


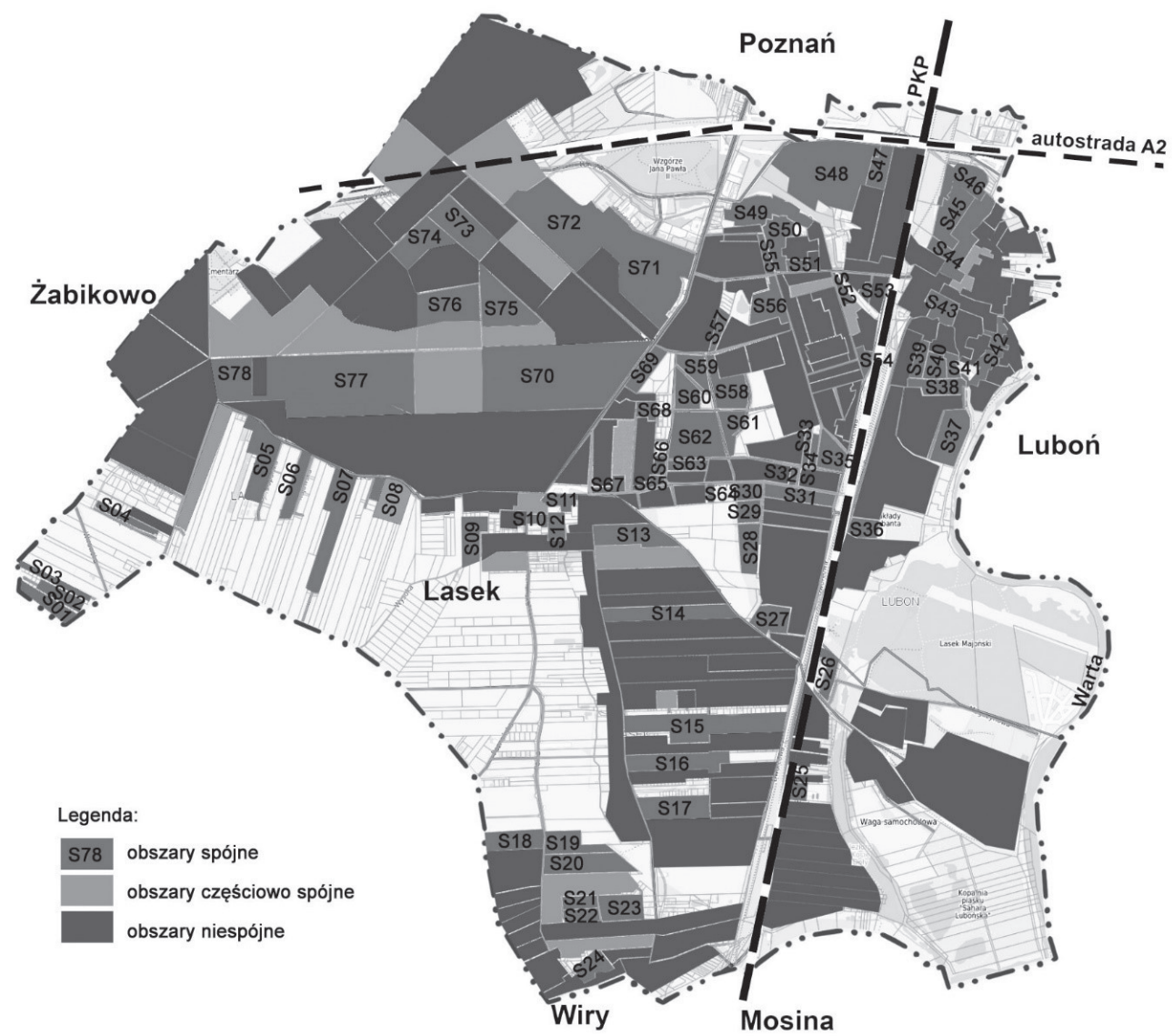

FIGURE 1. Location of coherent, partially coherent and incoherent areas in the Luboń commune

or black covering, and with white, grey, brown or beige external walls.

In each area, the indicators of dominance of the individual analysed physical characteristics of the buildings were also calculated; for the abovementioned area marked 059 they were:

- $100 \%$ - building height: 4,5 and 7 floors,

- $100 \%$ - type and geometry of the roof: flat roof, with a pitch slope of about $3^{\circ}$,

- $100 \%$ - roof colour: grey and graphite,
- $100 \%$ - external wall colour: white, grey, brown and beige.

The signature of the area in question does not take into account non-dominant physical characteristics:

- $50 \%$ - location of buildings in accordance with existing building alignment,

- as well as the location of the buildings in relation to the road, due to the fact that there are only buildings with flat roofs.

In the opinion of the authors, the signatures make the analysis more 
TABLE 2. Fragment of the analysis presenting the predominant features of buildings in coherent areas of the Luboń commune

\begin{tabular}{|c|c|c|c|c|c|c|c|}
\hline Area & $\begin{array}{c}\text { Area } \\
\text { size } \\
\text { (ha) }\end{array}$ & $\begin{array}{c}\text { Number } \\
\text { of } \\
\text { storeys }\end{array}$ & $\begin{array}{l}\text { Location } \\
\text { of the } \\
\text { building } \\
\text { in relation } \\
\text { to the road }\end{array}$ & $\begin{array}{c}\text { Maintenance } \\
\text { of building } \\
\text { alignment }\end{array}$ & $\begin{array}{l}\text { Type and } \\
\text { geometry } \\
\text { of the roof }\end{array}$ & $\begin{array}{l}\text { Colour } \\
\text { of the roof }\end{array}$ & $\begin{array}{l}\text { External } \\
\text { walls } \\
\text { colour }\end{array}$ \\
\hline S01 & 1.46 & 2 & - & yes & mixed & black, grey & $\begin{array}{l}\text { white, beige, } \\
\text { grey }\end{array}$ \\
\hline S02 & 1.44 & 2 & - & yes & mixed & - & $\begin{array}{l}\text { white, beige, } \\
\text { grey }\end{array}$ \\
\hline S03 & 1.22 & 2 & - & yes & flat & black, grey & white \\
\hline S04 & 0.94 & 2 & ridged & yes & gable & black, grey & white \\
\hline S05 & 3.92 & 1 & - & partly & hip $30^{\circ}$ & brown & beige \\
\hline S06 & 0.85 & 2 & ridged & yes & gable $45^{\circ}$ & black, grey & $\begin{array}{l}\text { white, grey, } \\
\text { brown }\end{array}$ \\
\hline S07 & 4.03 & $1-2$ & - & yes & gable, flat & - & white, beige \\
\hline S08 & 0.44 & 3 & $\begin{array}{l}\text { ridged, } \\
\text { peaked }\end{array}$ & yes & gable & black, grey & $\begin{array}{l}\text { beige, } \\
\text { brown }\end{array}$ \\
\hline S09 & 1.68 & 2 & ridged & yes & gable $45^{\circ}$ & brown & white \\
\hline $\mathrm{S} 10$ & 0.32 & $2-3$ & - & yes & flat & black, grey & white, beige \\
\hline $\mathrm{S} 11$ & 0.94 & 2 & ridged & partly & gable, hip $45^{\circ}$ & brown & white, beige \\
\hline $\mathrm{S} 12$ & 0.59 & 2 & & yes & flat roof & black, grey & white, beige \\
\hline $\mathrm{S} 13$ & 3.00 & - & $\begin{array}{l}\text { ridged, } \\
\text { peaked }\end{array}$ & yes & $\begin{array}{l}\text { gable, hip } 30^{\circ} \\
\& 45^{\circ}\end{array}$ & $\begin{array}{l}\text { black, grey, } \\
\text { brown }\end{array}$ & white, beige \\
\hline S14 & 4.62 & 2 & - & no & $\begin{array}{c}\text { gable, mixed } 30^{\circ} \\
\& 45^{\circ}\end{array}$ & $\begin{array}{l}\text { black, grey, } \\
\text { brown }\end{array}$ & white, beige \\
\hline $\mathrm{S} 15$ & 6.71 & 2 & peaked & yes & gable $45^{\circ}$ & black, grey & white, beige \\
\hline S16 & 3.74 & 2 & $\begin{array}{l}\text { ridged, } \\
\text { peaked }\end{array}$ & yes & $\begin{array}{c}\text { gable, mixed } 30^{\circ} \\
\& 45^{\circ}\end{array}$ & $\begin{array}{l}\text { red, black, } \\
\text { grey, brown }\end{array}$ & white, beige \\
\hline S17 & 3.15 & 2 & $\begin{array}{l}\text { ridged, } \\
\text { peaked }\end{array}$ & yes & $\operatorname{mixed} 30^{\circ} \& 45^{\circ}$ & - & beige \\
\hline $\mathrm{S} 18$ & 2.48 & 2 & $\begin{array}{l}\text { ridged, } \\
\text { peaked }\end{array}$ & yes & $\operatorname{mixed} 30^{\circ} \& 45^{\circ}$ & $\begin{array}{l}\text { black, grey, } \\
\text { brown }\end{array}$ & $\begin{array}{l}\text { white, beige, } \\
\text { red }\end{array}$ \\
\hline S19 & 2.16 & - & $\begin{array}{l}\text { ridged, } \\
\text { peaked }\end{array}$ & no & gable $30^{\circ} \& 45^{\circ}$ & red, brown & $\begin{array}{l}\text { white, beige, } \\
\text { green }\end{array}$ \\
\hline $\mathrm{S} 20$ & 3.47 & 2 & $\begin{array}{l}\text { ridged, } \\
\text { peaked }\end{array}$ & yes & gable $30^{\circ} \& 45^{\circ}$ & $\begin{array}{l}\text { red, black, } \\
\text { grey }\end{array}$ & white, beige \\
\hline
\end{tabular}




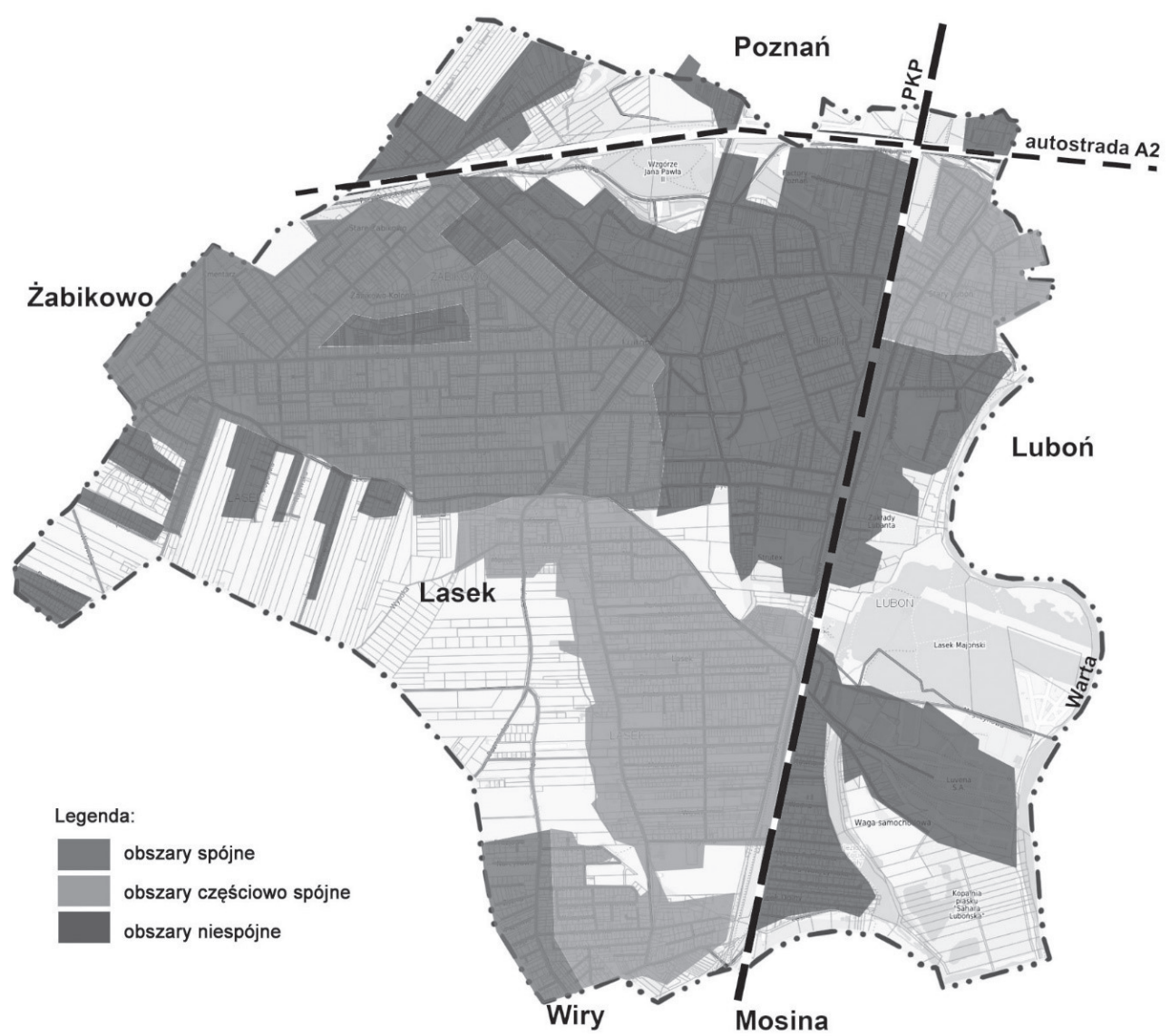

FIGURE 2. Fragment of the map of Luboń supplemented with signatures indicating the dominant physical features of buildings

accessible to recipients, and the physical characteristics of the buildings that dominate in a given area are more transparent and may constitute a more detailed alternative to notes on the drawings in studies of the conditions and directions of the spatial development of municipalities, or even local spatial development plans.

\section{CONCLUSIONS}

The article presents a method of partial space monitoring based on characteristics of the physical properties of build- ings located in a given area. In order to make the results more accessible to the public, they are presented in the form of a map of areas with different degrees of cohesion. They have been supplemented with a signature system showing the dominant physical characteristics in each area. Data collected during future field searches will broaden the state of knowledge about developed areas, and will make it possible to obtain detailed comparative material. It should show the scale and type of spatial changes in the analysed areas. 
The monitoring system presented in the manuscript will be refined and supplemented over the years. In the future, it is planned to carry out the survey in other regions of the Poznan area, as well as to develop the system with a comprehensive space monitoring system, which will require cooperation with specialists from other areas of design and spatial planning.

The authors hope that the results of the study will provide in-depth information about the development of individual areas in an accessible way and will allow for a better understanding of the local forms of developments among the participants of the construction process, as well as raise the architectural awareness of the residents.

All these activities are consequently aimed at improving the condition of space in developed areas.

\section{REFERENCES}

ALEXANDER C. 2002: The nature of order book 2 - the process of creating life. Center for Environmental Structure, University of California, Berkeley.

ALEXANDER C., ISHIKAWA S., SILVERSTEIN M., JACOBSON M., FIKSDAHL-KING I., ANGEL S. 1977: A Pattern Language. Oxford University Press. New York.

CALISKAN O., MASHHOODI B. 2017: Urban coherence: a morphological definition. Urban Morphol. 21 (2): 123-141 Retrieved from: www.researchgate.net/ /publication/320127428_Urban_Coherence_A_Morphologicāl_Definition: 123-141 [accessed: 17.07.2020].

EWING R., CLEMENTE O. 2013: Measuring urban design: metrics for liveable places. Island Press, Washington.
KANTAREK A.A. 2008: Rynek Krowoderski - w poszukiwaniu lokalnego centrum [Krowoderski Market Square - in searching of local center]. Czasopismo Techniczne. Architektura 105 (3-A): 65-74.

KANTAREK A.A. 2010: Tranzyt a spójność formy miasta [Transit and cohesion of urban form]. Czasopismo Techniczne. Architektura 107 (1-A): 164-170.

KOLIPIŃSKI B. 2011: Ład przestrzenny w Polsce - stan i problemy. Ekspertyza [Spatial order in Poland - Condition and Problems. Expertise]. Warszawa. Retrieved from: https://www.mir.gov.pl/ rozwoj regionalny/Ewaluacja i analizy/ Raporty_o_rozwoju/Raporty_-_krajowe/ Documents/Ekspertyza_Lad_przestrzenny_w_Pol $\backslash$ uFFFEsce_stan_i_problemy_ 20072011.pdf [accessed: 06. 06.2019 ].

KOWALEWSKI A., NOWAK M.J. 2018: Studia KPZK - Tom 182. Studia nad chaosem przestrzennym - cz. 1. Chaos przestrzenny i prawo. Uwarunkowania, procesy, skutki, rekomendacje [KPZK Studies - Vol. 182. Studies on Spatial Chaos - part 1. Spatial Chaos and Law. Conditions, Processes, Effects, Recommendations]. Polska Akademia Nauk Komitet Przestrzennego Zagospodarowania Kraju, Warszawa.

KOZŁOWSKI L., WAJER Z., BRZEZIŃSKA-RAWA A., DZIEKOŃSKI O., BIELSKA B., BIREK E., FLANZ S., GOSZCZYŃSKI W., KARWACKI A., KNIEĆ W., KOZIŃSKI G., KUROWSKA I., MARCINIAK Ż., MARCYSIAK T., MENTKOWSKI P., MUSZYŃSKA-JELESZYŃSKA D., PODHORECKI A., ROGATKA K., SKOWROŃSKI J. W., SKRZATEK M., SOBCZAK-PIATSTKA J., SOBIECH M., WINCEK A., WROŃSKA A., WROŃSKI S. 2017: Kształtowanie ładu przestrzennego w województwe kujawsko-pomorskim: Diagnoza i działania [Shaping spatial order in the Kujawsko-Pomorskie Voivodeship: Diagnosis and actions]. Wydawnictwo Naukowe Uniwersytetu Mikołaja Kopernika, Toruń. 
LYNCH K. 1990: Quality in City Design. In: T. Banerjee, M. Southworth (Eds.), City Sense and City Design. Writings and Projects of Kevin Lynch. The MIT Press, Cambridge.

MAKI F. 1964: Investigations in collective form. Washington University School of Architecture, St. Louis.

NIEZABITOWSKI A. 2006: Podstawowe elementy oceny wizualnego oddziaływania obiektów architektonicznych na środowisko [The basic elements of assessment of architectural object visual impact on the environment]. In: E. Niezabitowska (Ed.), Badania jakościowe środowiska zbudowanego. Stowarzyszenie Psychologia i Architektura, Poznań.

PODAWCA K. 2016: Wysokość zabudowy i forma dachu jako czynniki kształtowania ładu przestrzennego w mieście [The Height of Buildings and the Form of a Roof as Factors Shaping the Spatial Orderina City]. Kwartalnik Naukowy Uczelni Vistula 4 (50): 85-97.

Projekt z dnia 23 listopada 2017 r. ustawy Kodeks urbanistyczno-budowlany [Draft of 23 November 2017 the Urban Planning and Construction Code]. Retrieved from: http://www.kzp-ptch.pl/images/2018/Prawo/KUB/KUB23112017.pdf [accessed: 05.06.2020].

SALINGAROS N.A. 2017: Design patterns and living architecture. Sustasis Press, Portland.

ŚLESZYŃSKI P., MARKOWSKI T., KOWALEWSKI A. 2018: Studia KPZK - Tom 182. Studia nad chaosem przestrzennym - cz. 3. Synteza. Uwarunkowania, skutki i propozycje naprawy chaosu przestrzennego [KPZK Studies - Vol. 182. Studies on Spatial Chaos - part 3. The Synthesis. Conditions, Effects and Improvement Proposals of Spatial Chaos]. Polska Akademia Nauk Komitet Przestrzennego Zagospodarowania Kraju, Warszawa.

WDOWICKA M., MIERZEJEWSKA L. 2012: Chaos w zagospodarowaniu przestrzennym stref podmiejskich jako efekt braku zintegrowanego systemu planowania (na przykładzie strefy podmiejskiej Poznania) [Chaos in Suburban Spatial Management as a Result of Missing Integrated Planning Systems (on the Example of the Suburban Zone of Poznań)]. Problemy Rozwoju Miast 1 (4): 40-52.

Streszczenie: Ocena spójności przestrzennej na obszarach podmiejskich na podstawie cech fizycznych budynków. Gwałtowna ekspansja budownictwa mieszkalnego na terenach podmiejskich powoduje, że obszary te są obecnie miejscem szczególnie narażonym na degradację przestrzenną, zanik tradycyjnych krajobrazów wiejskich, a także rozmaite problemy będące następstwem tych zjawisk. Brak spójności przestrzennej tych terenów jest jednym $z$ elementów pogłębiających nieład przestrzenny. Przedmiotem prezentowanych badań są fizyczne cechy form budynków, które poprzez swoją rolę w kształtowaniu kontekstu przestrzennego wpływają na ład przestrzenny. Autorzy badania postawili sobie za cel opracowanie metody monitoringu przestrzeni opierającej się na charakterystyce cech fizycznych budynków zlokalizowanych na danym obszarze. Wyniki badania mają dostarczyć w przystępny sposób dogłębnej informacji o zabudowie poszczególnych terenów oraz pozwolić na lepsze poznanie miejscowych form budynków uczestnikom procesu budowlanego, a także podnieść świadomość architektoniczną mieszkańców.

Słowa kluczowe: monitoring przestrzeni, spójność przestrzenna, ład przestrzenny

MS received: 14.01 .2020

MS accepted: 03.08.2020

Authors' address:

Joanna Kołata

(https://orcid.org/0000-0003-2465-866X)

Piotr Zierke

(https://orcid.org/0000-0002-9460-2920)

Zakład Architektury Miejsc Pracy i Rekreacji

Instytut Architektury i Planowania

Przestrzennego

Politechnika Poznańska

ul. Nieszawska 13c, 61-032 Poznań

Poland

e-mail: piotr.zierke@put.poznan.pl 